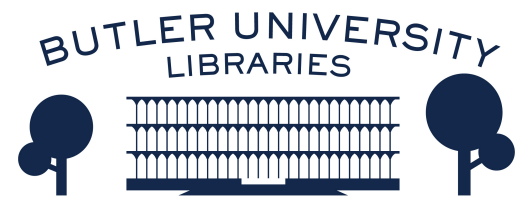

Journal of Hindu-Christian Studies

Volume 25

Article 20

November 2012

\title{
Book Review: "Oxford Bibliographies: Hinduism and Christianity"
}

Christopher R. Conway

Follow this and additional works at: https://digitalcommons.butler.edu/jhcs

Part of the Religion Commons

\section{Recommended Citation}

Conway, Christopher R. (2012) "Book Review: "Oxford Bibliographies: Hinduism and Christianity"," Journal of Hindu-Christian Studies: Vol. 25, Article 20.

Available at: https://doi.org/10.7825/2164-6279.1526

The Journal of Hindu-Christian Studies is a publication of the Society for Hindu-Christian Studies. The digital version is made available by Digital Commons @ Butler University. For questions about the Journal or the Society, please contact cbauman@butler.edu. For more information about Digital Commons @ Butler University, please contact digitalscholarship@butler.edu. 
of the connections pursued further and their implications elaborated.

Reid's readers, however, are not limited to the community of Christians. This Christian commentary on a Hindu sacred text is likely to be read also by Hindu Advaita theologians (like this reviewer!) who become participants in this conversation between the Christian theologian and reader. What does the Advaitin reader gain? Certainly, a deeper understanding of the Christian theological tradition offered in context of an empathetic study of a Hindu text. For Advaitins, who engage in dialogue with Christians, the learning afforded by Reid's work is invaluable. There is an invitation here also to reconsider important dimensions of the Advaita tradition, often taken for granted, such as the ethic of renunciation, the overcoming of desire, attitudes to physicality, and the status of the other. "There can be no true love and care for others, in other words, where there are no true others to love (p.315)." Reid highlights these issues, cognizant of similar problems in the Christian tradition and the ambiguities associated with the Christian understanding and practice of agape. His critical treatment of Advaita is not one-sided.

Reid's work on the Upadesasahari reflects the rigorous demands of good comparative theology. There is no simplistic conflation of Shankara;s theology with Christianity and Reid recognizes that there are issues, jivanmukti, for example, over with reconciliation may not be possible. He immerses himself deeply and reverentially in text and tradition, suggesting both familiar and novel places for mutual reflection and deep learning. His work demonstrates the possibility of fruitful study of another tradition from a location of commitment to one's own and reverence for the sacred worth of the other.

Anantanand Rambachan

St. Olaf College

\section{Oxford Bibliographies: Hinduism and Christianity. Edited by Chad Bauman,}

\section{Arun Jones, Brian Pennington, Joseph Prabhakar Dayam, and Michelle Voss Roberts, 2012: http://www.oxfordbibliographies.com/ view/document/obo-9780195399318/obo-9780195399318-}

\section{2.xml?rskey=zjee Zu\&result $=2 \& q=$}

THE online, annotated bibliography Hinduism and Christianity is a welcomed, if curiously placed, addition to the Oxford Bibliographies project. Located within the project's subsection on Hinduism and alongside a diverse array of bibliographies that range from Abhinavagupta to yoga and from architecture to politics, Hinduism and Christianity provides a thorough and well-balanced introduction to scholarship on the historical, social, and theological developments of Christianity in India. Although its present content focuses primarily on Christianity in India-the bibliography's content will continue to growit does well to include sections on Hindu responses to Christianity, the impact of Hindu theology and philosophy on theological reflection occurring outside of India, and the Hindu diaspora's encounters with Christianity in the United States and Europe. As the editors note, this field of study is as complicated as it is diverse. Their bibliography is a rich resource that will help both the seasoned scholar and novice inquirer explore more deeply the generals and specifics of Christian and Indian interactions.

Chad Bauman, Arun Jones, Brian Pennington, Joseph Prabhakar Dayam, and Michelle Voss Roberts comprise the project's editorial team. Each brings to the bibliography his or her specialization and expertise, which help to ensure the quality of resources across this wide field. The works these editors have culled together demonstrate the inter- 
religious, ecumenical, historically sweeping, and geographically expansive nature of this sometimes antagonistic, sometimes amicable, but almost always dynamic interaction. For those familiar with the field in general or a subsection in particular, many of these selections will not be new. They are a 'best of' compilation, and when taken as a whole they provide a useful and quite fascinating account of Christianity's encounters with Indian culture and Hinduism as well as a genealogy of the methodological developments in the study and theology that result from them.

The bibliography is divided into twentythree sections and contains nearly one hundred and fifty selections including prominent journals in the field, books, book-chapters, and articles. These sections, each possessing an informative introduction to the proceeding texts, can be grouped into three overarching categories: the historical, the theological, and the conflictual. The historical-general, regional, missional, and methodological-and the theological-intercultural, textual, and dialogical-enjoy the lion's share of entries. The conflictual-polemics, conversion debates, and diasporic experiences-contains the majority of selections coming from a Hindu perspective. As the bibliography continues to grow, a greater selection from Hindu authors would be welcomed. Though source material on Hinduism's theological engagement with Christianity is less abundant than Christianity's, its inclusion would help to fill a lacuna in scholarship and provide interesting points for comparison

The succinct yet detailed annotations accompanying each selection avoid the too frequent practice of simply re-presenting the work's title as a sufficient means of commentary. Instead, they highlight the significance of the work for the field, offer its thesis, and briefly comment on its approach. The editors shy neither from praise nor criticism where appropriate. In doing so, they remind one that the great contributions that previous generations have made while at times might be 'dated,' are nevertheless the fertile grounds from which present scholarship flourishes. Fifty words can convey a great deal when written thoughtfully.

The ever-increasing digitalization of scholarship presents both opportunities and problems. The resources now available online are plentiful, but search engines are governed by their own algorithms and do not necessarily account for the quality of scholarship in the materials they make so readily available. In providing this bibliography, the editors have wedded the positives of digitalization with the benefits of the peer-reviewed process. When the bibliography is accessed through a host institution's online library, it operates as a bibliography 2.0. Each selection possesses a link that allows one to locate a copy of the text in one's library-either in the stacks or online. should one's library not have a copy, WorldCat and Google Books are both a click away, allowing either for a copy to be sent via interlibrary loan or quick glimpse of text's available content. Such amenities, however, come with a price. The bibliography and its features are secured behind the oxford Bibliographies' firewall. One requires a subscription, or more probably one requires affiliation with an institution that has a subscription, to access the content. For those persons and institutions out beyond the firewall, a hard-copy version of the bibliography is not yet available.

Obscured by the shadows cast from the monograph, the article, and the book review, the annotated bibliography seldom enjoys its place in the academic limelight. When done well, as is the case here, it is an invaluable resource capable of elegantly and economically opening up an entire field of study. Those able to access this wonderful bibliography will certainly benefit from the hard-toiled for fruits these editors provide. Hinduism and Christianity is a boon for scholars, teachers, and students.

Christopher R. Conway

Boston College 